\title{
Social Study And Economic Aspects Of Sheep In Intensive Livestock Business District Cirebon
}

\author{
Fitri Dian Perwitasari \\ Study Program Of Animal Science \\ Muhammadiyah University Of Cirebon \\ Cirebon, Indonesia \\ caraka20@gmail.com
}

\author{
Bastoni \\ Study Program Of Animal Science \\ Muhammadiyah University Of Cirebon \\ Cirebon, Indonesia \\ al basthonie@yahoo.com
}

\begin{abstract}
Haur Kuning Livestock Farmer Group is located in Ciawi Gajah Village, Cirebon District. Members of the Haur Kuning livestock farming group have intensive maintenance methode in raising their livestock with varying business scales. The research was conducted to know the socio-economic aspects of intensive sheep breeding in Cirebon District. Purposive sampling was used to determine the location of the research. Primary data was obtained from interviews with the Haur Kuning group, while for secondary data came from the Cirebon District Agriculture Office, literature of research journals, books, and scientific articles. The collected data was analyzed using descriptive tabulation then calculated using the income formula and $\mathrm{R} / \mathrm{C}$ ratio analysis. The results showed that the results in a social aspect: 1) the members of the Haur Kuning sheep group still thought that they ran the business as a savings and an activity in their free time before the harvest, 2) the majority of the main worker respondents were farmers so they could use the agricultural products for animal feed availability. In this economic aspect, the lowest income Rp. 393,500 and the highest were $R p .10,418,500$ and the lowest $R / C$ ratio analysis was 1.20 and the highest was 6.26 .
\end{abstract}

Keywords-economic, intensive sheep, income and $R / C$ ratio, social aspects

\section{INTRODUCTION}

Cirebon Regency is one of the regions that has a total population of 260,000 sheep which is divided throughout the Regency of Cirebon. Geographical conditions, weather, climate and forage availability in Cirebon Regency are suitable for sheep business. This is supported by the opinion said that "technically sheep have a high tolerance for various forages and good environmental adaptation" [1].

Haur Kuning Livestock Farmers Group located in Ciawi Gajah Village, Beber Subdistrict. This is a location of sheep farmer groups which maintenance has been intensively managed with varying business scales. Role of sheep in the Haur Kuning cattle farmer group is as additional income for farmers or as savings, as one of the livestock commodities as a source of animal protein for the community, fill the spare time, and produces manure. Traditional sheep breeding, feeding only depends on natural availability and agricultural waste in the surrounding environment without regard to the nutritional standards of livestock. This traditional maintenance can still survive even though the production side is not optimal. This study was conducted to find out the social aspects, which were seen from the livestock experience and the main livelihood of farmers. The economic aspects of intensive sheep livestock business in Cirebon Regency were seen whether the business provide profit or not.

\section{METHODS}

The place of this research was held in Haur Kuning Livestock Farmer Group of Ciawi Gajah Village, Beber Subdistrict, Cirebon Regency in March - June 2018. The method of determining the location by purposive sampling where the selection of locations was deliberately chosen by the researcher because the Haur Kuning cattle farmer group had an intensive sheep breeding system and it is a group of sheep farmer that still survive in Cirebon Regency. The method used in this study was the observation method, the collection of primary data obtained from interviews with the Haur Kuning sheep farmer group, samples taken from 11 respondents from 19 members of the Haur Kuning farmer group. the secondary data came from the Cirebon District Agriculture Office and journal literature, research, books and scientific articles. The data collected from interview respondents were then analyzed using descriptive tabulation and calculated using the income formula and $\mathrm{R} / \mathrm{C}$ ratio analysis.

A. Income Formula [2]

$\mathrm{Pd}=\mathrm{TR}-\mathrm{TC}$

Information :

$\mathrm{Pd}=$ Income

$\mathrm{TR}=$ Total Revenue

$\mathrm{Y}=$ Production obtained from sheep business

Py = Production Price y

$\mathrm{TC}=$ Total Cost

$=\mathrm{FC}+\mathrm{VC}$

Information:

$\mathrm{FC}=$ Fixed cost

$\mathrm{VC}=$ Variable costs

\section{B. $R$ / C ratio analysis}

To find out how much revenue will be obtained from each rupiah that will be spent by farmers for sheep business activities.

\section{$R / C$ ratio Formula $[3]$}

$\mathrm{R} / \mathrm{C}$ ratio $=\frac{T R}{T C}$ 
Information :

$\mathrm{R} / \mathrm{C}=$ balance of revenues and costs

$\mathrm{TR}=$ Total Revenue

$\mathrm{TC}=$ Total Cost

\section{RESULTS AND DISCUSSION}

\section{A. Characteristics of Respondents}

The factor of human resources greatly influences the sustainability of business activities. Therefore the characteristics of the respondent members of the Haur Kuning livestock farmer group interviewed will be explained below including (1) History of Haur Kuning farmer group, (2) age, (3) education level, (4) farming experience.

\section{B. History of the Haur Kuning Farmer Group}

Respondents were a members of the Haur Kuning sheep farmer group. The Haur Kuning sheep farmer group was established in 2003 until now, the number of group members contained 19 members with an organizational structure that has their respective duties and obligations below. However, from the beginning of the establishment of this farmer group was no change in the head of the livestock farmer group, thus causing new members to replace the old members to not play an active role in advancing the group.

Table 1. Organizational Structure of Haur Kuning Livestock Farmers Group

\begin{tabular}{ccc}
\hline No & Organizational Structure & Name \\
\hline 1 & Chairman & Sadiman \\
2 & Secretary & Sutardi \\
3 & Treasurer & Rutija \\
4 & PR & Sahidin \\
5 & Administration & Rohim \\
6 & Security & Akrawi \\
7 & Cleanliness & Sukar \\
8 & Building & Satibi \\
9 & Marketing & Suwawi \\
\hline
\end{tabular}

\section{1) Age Respondents}

The results of observations and interviews with respondents from the Haur Kuning livestock farmer group aged between $21-50$ years $(81.82 \%)$. These results indicated that the average respondent was still in the productive age range. "This productive age still has the energy, and motivation to try to advance further in sheep farming "[4]. This was also supported by this productive age opinion "which can facilitate the absorption of knowledge, technology and information delivered to support livestock business and sheep productivity" [5].

Table 2. Age of Haur Kuning Livestock Farmers Group Respondents

\begin{tabular}{cccr}
\hline No & Age (Years) & Total & \multicolumn{2}{c}{ Percentage (\%) } \\
\hline 1 & $21-50$ & 9 & 81.82 \\
2 & $>51$ & 2 & 18.18 \\
\hline & Total & 11 & 100.00 \\
\hline
\end{tabular}

\section{2) Education level}

The results of this study indicated the lowest education of the Haur Kuning livestock farmer group, namely only elementary school graduates. This was supported by the opinion of [4] who said that farmers with the lowest primary education, they could run sheep business based on the experience passed down by the former farmers. According to [6] the higher the level of education will affect the performance in accepting innovation the easier. So as to provide information, knowledge and technology are given continuous training and accompaniment. According said that "the factors of human resources, especially aspects of education need to be done in order to be able to respond to all developments that occur" [4].

Table 3. Education Level of Haur Kuning Livestock Farmers

\begin{tabular}{clcc}
\multicolumn{2}{c}{ Group } & Total & Percentage (\%) \\
\hline NO & \multicolumn{1}{c}{ Education Level } & 1 & 9,09 \\
\hline 1 & Not completed in primary school & 9 & 81,82 \\
2 & Elementary school & 1 & 9,09 \\
3 & Middle school & 0 & 0 \\
4 & High school & 0 & 0 \\
5 & College & 11 & 100 \\
\hline & & &
\end{tabular}

\section{3) Experience Farming}

The results of observations and interviews with respondents from the Haur Kuning livestock farmer group experience breeding ranged from 1 - 10 years. "The experience of raising livestock for 1 - 10 years actually has gained skills in managing sheep well" [4].

Table 4. Experience Farming of Haur Kuning Farmers Group

\begin{tabular}{cccr}
\hline No & Experience Farming & Total & Percentage (\%) \\
\hline 1 & $1-10$ years & 6 & 54,55 \\
2 & $>10$ years & 5 & 45,45 \\
\hline & Total & 11 & 100.00 \\
\hline
\end{tabular}

\section{Social aspects}

The social aspects discussed in this study include (1) Farm Business Goals and (2) the livelihoods of respondents which will be explained below.

\section{1) Farm Business Goals}

The results of this study indicated that the livestock business objectives almost reached $90 \%$ more as a respondent's side business. The reason respondents said that it was a side business because (1) utilizing free time, (2) utilizing farmer's waste for animal feed, (3) utilizing sheep waste for fertilizer.

Table 5. The purpose of the Haur Kuning Farmer Group breeding business

\begin{tabular}{|c|c|c|c|}
\hline $\mathrm{NO}$ & Farming Goals & Total & Percentage (\%) \\
\hline 1 & Side & 10 & 90,91 \\
\hline 2 & Commercial & 1 & 9,09 \\
\hline 3 & Savings & 0 & 0.00 \\
\hline \multirow[t]{2}{*}{4} & There is no & 0 & 0.00 \\
\hline & Total & & 100 \\
\hline
\end{tabular}




\section{2) Respondents Main Livelihood}

The results of this study indicated that the main work of members of the Haur Kuning farmer group was $81.82 \%$ as Farmers. These results indicated that the reason they raised livestock was not the main goal of raising livestock. This was supported by the opinion [1] that the main livelihoods of respondents as farmers were 58 people $(84.6 \%)$, sheep business as a side business which was an additional source of family income.

Table 6. Main Livelihood Respondents

\begin{tabular}{|c|c|c|c|}
\hline No & Main Livelihood & Total & Percentage (\%) \\
\hline 1 & farm workers & 1 & 9.09 \\
\hline 2 & Farming & 9 & 81.82 \\
\hline 3 & Entrepreneur & 1 & 9.09 \\
\hline & Total & 11 & 100 \\
\hline
\end{tabular}

The results of the explanation above can be stated that this research was the social aspect of the Haur Yellow Livestock Farmer Group:

(1) members of the Haur Kuning sheep group still thought that raising sheep would give many benefits as a savings and filling their free time waiting for the harvest time. Farmers in this business never count the profits received.The revenue they got was not routinely every year but farmers would sell it when they need money for their family.

(2) the majority of the main worker respondents were farmers so they utilized the remaining agricultural products for the availability of sheep feed. The need for feed costs was only issued by 7 respondents to buy additional livestock feed (can be seen in table 9).

\section{Economic aspects}

The economic aspects discussed in this study include: (1) Revenue, (2) Production Costs, (3) Income Analysis and R / $\mathrm{C}$ ratio which will be explained below.

Table 7. Livestock Farmer Group total Revenues

\begin{tabular}{lrrr}
\hline No & $\begin{array}{c}\text { The selling price of } \\
\text { livestock The } \\
\text { number of livestock } \\
\text { sold }\end{array}$ & $\begin{array}{c}\text { The selling price of } \\
\text { livestock The number of } \\
\text { livestock sold }\end{array}$ & \multicolumn{1}{c}{$\begin{array}{c}\text { Total } \\
\text { Revenue }\end{array}$} \\
\hline 1 & 1.550 .000 & 8 & 12.400 .000 \\
2 & 1.550 .000 & 3 & 4.650 .000 \\
3 & 2.550 .000 & 3 & 7.650 .000 \\
4 & 800.000 & 3 & 2.400 .000 \\
5 & 800.000 & 3 & 2.400 .000 \\
6 & 1.550 .000 & 3 & 4.650 .000 \\
7 & 800.000 & 3 & 2.400 .000 \\
8 & 800.000 & 3 & 2.400 .000 \\
9 & 1.550 .000 & 3 & 4.650 .000 \\
10 & 800.000 & 3 & 2.400 .000 \\
11 & 1.550 .000 & 3 & 4.650 .000 \\
\hline
\end{tabular}

\section{1) Revenue}

The acceptance of sheep business in the Haur Kuning cattle farmer group was the sale of sheep that was ready to sell by sheep farmers. The selling price of livestock varies with the selling price of Rp. 800,000, Rp. 1,550,000 and Rp. 2,550,000 per head. This was in accordance with the opinion [4] that real revenue is the number of results received from the sale of the product while the revenue calculated is derived from the added value of livestock. The average sale of livestock in the form of life through collecting traders who come to the villages and some of them sell directly outside the village or island in a forced situation such as sick sheep or need immediate funding.

\section{2) Production cost}

Production costs were costs incurred by farmers to raise sheep. Production costs were divided into two, namely fixed costs and non-fixed costs. Fixed costs for sheep breeding include cage depreciation costs, depreciation of equipment and depreciation of livestock costs. Depreciation of livestock

\begin{tabular}{ccrr} 
Table 8. Total Fixed Cost & & \\
\hline No & $\begin{array}{c}\text { Depreciation costs } \\
\text { enclosure }\end{array}$ & $\begin{array}{c}\text { Depreciation } \\
\text { Equipment }\end{array}$ & $\begin{array}{c}\text { Livestock } \\
\text { Depreciation Costs }\end{array}$ \\
\hline 1 & 310.000 & 550.000 & 460.000 \\
2 & 710.000 & 275.000 & 360.000 \\
3 & 710.000 & 275.000 & 260.000 \\
4 & 710.000 & - & 260.000 \\
5 & 710.000 & 275.000 & 360.000 \\
6 & 710.000 & 275.000 & 260.000 \\
7 & 710.000 & 275.000 & 360.000 \\
8 & 710.000 & 275.000 & 160.000 \\
9 & 710.000 & 275.000 & 160.000 \\
10 & 710.000 & 275.000 & 360.000 \\
11 & 710.000 & 275.000 & 460.000 \\
\hline
\end{tabular}

The results of this study the majority of farmer said that the cost of making their cages between IDR. 2,100,000 - Rp. $5,000,000$ with a period of 5 years, while the enclosure equipment that the respondents issued were shovels, sickles, carts, and buckets. IDR $100.000-1,000,000$ with 2 years. Members of the Haur Kuning livestock farm group maintain breeding and fattening. Livestock breeds of male sex will be fattened, while for females, females will be used as broodstock. Breeders who can still breed will continue to be maintained by farmers, therefore we calculate the value of depreciation of livestock. The initial price of this broodstock varies from IDR. 800,000 / tail, IDR. 1,300,000 / tail and IDR. 2,300,000 / tail.

\section{3) Variable cost}

Non-permanent costs incurred include feed costs and drug costs. The cost of feed was still the highest of all production costs, the cost of feed was IDR 550,000 or $83.14 \%$ of the total production costs. According to [4] Activities carried out by farmers in livestock raising include weeding grass, feeding, cleaning cages, bathing livestock and mating sheep [7]. The labor unit is one working day, the time given to a person for one day. Drug costs incurred by the respondent are less than IDR. 20,000.

\begin{tabular}{crrr}
\multicolumn{5}{l}{ Table 9. Variable cost } \\
\hline \multicolumn{1}{c}{ No } & Feeds Cost & Medicine Cost & Labor Cost \\
\hline 1 & 550.000 & 10.500 & 0 \\
2 & 550.000 & 0 & 0 \\
3 & 550.000 & 10.500 & 0 \\
4 & 550.000 & 10.500 & 0 \\
5 & 550.000 & 10.500 & 0 \\
6 & 0 & 35.500 & 0 \\
7 & 550.000 & 10.500 & 0 \\
8 & 550.000 & 10.500 & 0 \\
9 & 0 & 10.500 & 0 \\
10 & 0 & 10.500 & 0 \\
11 & 0 & 10.500 & 0 \\
\hline
\end{tabular}

The low cost of purchasing drugs for livestock was not mean that livestock was not pay attention and never sick, but 
the respondent gave human's medicine to their livestock, for example if the cattle was bloated, they would be given ulcer medication. Labor costs were not taken into account by respondents because the farmer used was still their own family, namely the wife or children of the respondent.

\section{4) Revenue Cost Ratio Revenue and Analysis}

Revenue received was as low as Rp. 393,500 and the highest opinion was Rp. 10,418,500. There was a difference in income due to (1) The selling price of livestock received by farmers was Rp. 800,000 / head, Rp. 1,550,000 / head and Rp. $2,550,000 /$ head, (2) The number of livestock sold in the past year with the majority was 3 and only one person could sell 6 . (3) and the total amount incurred. This was in accordance with the opinion [8], the selling price of children is also a factor that influences the income received by farmers in the business of goats. According to [9] stating that the large number of livestock holdings affects income, the more ownership of livestock, the higher the income, while if there is a loss, it will also receive losses.

Table 9. Income Analysis and $\mathrm{R} / \mathrm{C}$ ratio

\begin{tabular}{lrrrr}
\hline No & \multicolumn{1}{l}{ Revenue } & \multicolumn{1}{l}{ Total Costs } & Income & \multicolumn{1}{r}{$\begin{array}{l}\mathrm{R} / \mathrm{C} \\
\text { ratio }\end{array}$} \\
\hline 1 & 12.400 .000 & 1.981 .500 & 10.418 .500 & 6.26 \\
2 & 4.650 .000 & 1.995 .000 & 2.655 .000 & 2.33 \\
3 & 7.650 .000 & 1.906 .500 & 5.743 .500 & 4.01 \\
4 & 2.400 .000 & 1.631 .500 & 768.500 & 1.47 \\
5 & 2.400 .000 & 2.006 .500 & 393.500 & 1.20 \\
6 & 4.650 .000 & 1.301 .500 & 3.348 .500 & 3.57 \\
7 & 2.400 .000 & 2.006 .500 & 393.500 & 1.20 \\
8 & 2.400 .000 & 1.806 .500 & 593.500 & 1.33 \\
9 & 4.650 .000 & 1.156 .500 & 3.493 .500 & 4.02 \\
10 & 2.400 .000 & 1.356 .500 & 1.043 .500 & 1.77 \\
11 & 4.650 .000 & 1.456 .500 & 3.193 .500 & 3.19 \\
\hline
\end{tabular}

This result could be the lowest $\mathrm{R} / \mathrm{C}$ ratio analysis of 1.20 and the highest of 6.26. The lowest $\mathrm{R} / \mathrm{C}$ ratio of 1.20 meant that every increase in costs incurred by Rp. 1000 can generate revenue of Rp. 1.20 as well as the highest of 6.26 , meaning that any increase in costs incurred by Rp. 1000 can generate revenue of Rp. 6.26. According to Pasaribu (2012) said that the $\mathrm{R} / \mathrm{C}$ ratio value shows the amount of revenue to be obtained from each rupiah that will be spent by farmers for sheep business activities.

\section{CONCLUSION}

The results of this study could be concluded that on a social aspect: 1) members of the Haur Kuning sheep herd still argued that the sheep business was a savings and an activity in the free time of farmers before the harvest. 2) the majority of the main worker respondents were farmer so they utilized the remaining agricultural products for the availability of sheep feed. In this economic aspect, the income received was as low as IDR 393,500 and the highest income was IDR $10,418,500$ and the lowest $\mathrm{R} / \mathrm{C}$ ratio analysis was 1.20 and the highest was 6.26 .

This sheep breeding business was profitable, to increase the income received by farmers, it was necessary to have continuous training and accompaniment from the government or educational institutions (universities) on technical matters (seeds, feed, cages, health, waste processing and marketing).

\section{ACKNOWLEDGMENT}

The author would like to express his gratitude and highest appreciation to the Ministry of Research, Technology and Higher Education for providing funds through the 2017 Junior Lecturer Research Scheme.

\section{REFERENCES}

[1] Siswati A. K. Yogie. Rahayu S. and Kuswaryan. S. Financial Feasibility Study The Lamb's Animal Care Maintained in Standing (Case Study in Cibuntu Village, Pasawahan District, Kuningan Regency) (Financial Feasibility Study of Sheep Intensive Management (Case Study in Sheep Farmer Cibuntu, Pasawahan District, Kuningan Regency). , December 2015, VOL.15, NO.2.

[2] Soekartawi. Farming Science and Smallholder Development. University Indonesia Press, Jakarta.

[3] Pasaribu, Ali Musa. Planning and Evaluation of Agribusiness Projects (Concepts and Applications). Lily Publisher Publisher. Yogyakarta.

[4] Welerubun, I.n. T. Ekowati. A.Setiadi. Profitability Analysis of livestock business in Kisar Sheep on Kisar Island Southwest Maluku Regency. Journal of Mediaagro. 2016.Vol 12 no 2 Page 39 - 47.

[5] Mastuti, S and N.N. Hidayati. The role of female workers in the business of dairy cattle in Banyumas Regency. 2009.JAP.11 (1): 40-47

[6] Badar, G.A, S.Rahayu and S. Kuswanyan.2014. Technical, Social and Economic Factors that Affect Sheep Farming Business Revenue.

[7] Cyrilla, L., Z. Moesa., M. P. Putri. Production efficiency of sheep farming in Cibunian Village, Pamijahan Subdistrict, Bogor Regency. 2010. Media Ranch 33 (1): 55-60.

[8] Parwati, I. A. P. Revenue and factors that influence the production of goat livestock business with laserpuncture. Bali Agricultural Technology Assessment Center. 2007.7 (1): 1-14.

[9] Ningsih, Y., N. N. Hidayat and O. E. Djatmiko. Analysis of income contribution and economic efficiency of broiler broiler business in Purbalingga Regency. 2013.J. Scientific Animal Husbandry. 1 (3): 1078-1085. 